\title{
No labirinto da educação infantil: as falas de educadoras sobre gênero e sexualidade
}

\author{
Cláudia Maria Ribeiro ${ }^{1}$
}

\begin{abstract}
Resumo: Este texto busca problematizar as falas de educadoras que atuam na Educação Infantil concebendo-as como enunciados. Esse é um conceito cunhado por Michel Foucault que gera perguntas tais como: o que pode ser dito? Quem está autorizado/a a dizer? Penetro então num labirinto de enunciados que são geradores de tantas perguntas: por que gênero e sexualidade são questões? Quais os governos exercidos por múltiplas forças, por autoridades que se consideram capazes de vigiar, julgar, marcar a sexualidade e o gênero? Por que ainda hoje as expressões da sexualidade das crianças causam tanta agitação? Qual o contexto em que as crianças, em algumas instituições de Educação Infantil, expressam sua sexualidade? Qual a concepção de sexualidade e como essa temática integra ou não os currículos de formação de educadores e educadoras? Que discursos legais, científicos, médicos, morais, religiosos, educacionais, jurídicos engalfinham-se na Educação Infantil? Todas essas perguntas constituem um emaranhado de caminhos - um labirinto - e desafiam nossa capacidade para pensar as multiplicidades e as interconexões desses discursos que podem ser produzidas no cotidiano da Educação Infantil.
\end{abstract}

Palavras-chave: Gênero; sexualidade; enunciado; educação infantil.

\begin{abstract}
This paper seeks to discuss about speeches of educators who work in the childhood education, conceiving them as statements. This is a concept coined by Michel Foucault, which generates questions such as: What can be said? Who is allowed to say? This way, I get into a labyrinth of statements which generate many questions, as follow: Why gender and sexuality are issues? Which governments are exerted by multiple forces, by authorities who are considered able to watch, judge, and mark the sexuality and gender? Why expressions about children sexuality cause such stir, so far? What is the context in which children express their sexuality in childhood education institutions? What is the conception of sexuality, and how this theme integrates or not the curricula of educators formation? What legal, scientific, medical, moral, religious, educational, and juridical speeches are discussed in the childhood education? All of these questions form a labyrinth, and challenge our capacity for thinking about the multiplicity and the interconnexions of these speeches, which may be obtained in the daily of childhood education.
\end{abstract}

Key-words: Gender. Sexuality. Statement. Childhood education.

Resumén: Este texto pretende reflexionar sobre las expresiones de las educadoras que actúan en la Educación Infantil, concibiéndolas como enunciados. Este es un concepto acuñado por Michel Foucault que genera preguntas tales como: ¿qué puede ser dicho?, ¿quién está autorizado a decirlo? Penetro entonces en un laberinto de enunciados que sugieren muchas preguntas: ¿por qué género y sexualidad son cuestiones?, ¿qué gobiernos ejercidos por múltiples fuerzas, por autoridades se consideran capaces de vigilar, juzgar, marcar la sexualidad y el género?, ¿cuál es la concepción de sexualidad y cómo esa temática integra o no los currículos de formación de educadores y educadoras?, ¿qué discursos legales, científicos, médicos, morales, religiosos, educacionales, jurídicos se discuten en la Educación Infantil? Todas esas preguntas constituyen una maraña de caminos -un laberinto- y desafían nuestra capacidad para pensar en las multiplicidades e interconexiones de esos discursos que pueden producirse en el cotidiano de la Educación Infantil.

Palabras clave: Género, sexualidad, enunciado, educación infantil

1 Professora Associada do Departamento de Educação da Universidade Federal de Lavras - MG. Líder do Grupo de Pesquisas/CNPq: Relações entre a Filosofia e Educação para a Sexualidade na Contemporaneidade: a Problemática da Formação Docente. 


\section{Haverá fio de Ariadne?}

A primeira etapa da Educação Básica - Educação Infantil - requer imensos desafios para a discussão das dimensões macro e micro de seu cotidiano. Gallo (2007) propõe os conceitos de Educação Maior e Educação Menor considerando o campo da macropolítica e da gestão, que se refere às leis, políticas públicas, metas, planos, cronogramas com vistas a implementar o grande sistema da educação. Já o campo da micropolítica refere-se às ações desenvolvidas nas salas de aula ultrapassando os limites das leis, das políticas e das determinações legais. No campo da macropolítica, o sistema de educação brasileiro incorpora, em 1988, a Educação Infantil como primeira etapa da Educação Básica. Em 1990, a lei federal 8069/90 formula o Estatuto da Criança e do Adolescente que explicita, entre os direitos da criança, o atendimento em creches e préescolas para as crianças de até os 6 anos de idade. Pela primeira vez, um texto constitucional define claramente como direito da criança de 0 a 6 anos de idade e dever do Estado, o atendimento em creche e pré-escola (CAMPOS; ROSEMBERG; FERREIRA, 1995, p.17-18). Aprova-se em 1996 a Lei de Diretrizes e Bases da Educação Nacional (LDBEN no. 9394/6).

De 1990 até 1996, o Ministério da Educação em conjunto com outros segmentos define uma política nacional para Educação Infantil, propondo a criação de uma Comissão Nacional de Educação Infantil (CNEI), com vistas a formular e implementar políticas na área, atuando de 1993 a 1996. Em 1994, aconteceu a Conferência Nacional de Educação para Todos, e um dos eventos preparatórios à conferência foi o I Simpósio Nacional de Educação Infantil, que aprovou a Política Nacional de Educação Infantil, com o apoio da CNEI. Acontece a Municipalização da Educação Infantil que passa a ser responsabilidade dos Municípios. Elaboram-se as Diretrizes Curriculares Nacionais para a Educação Infantil (Res. CNE/CEB, no. 5 de 17 de dezembro de 2009).

Atualmente navegamos pelas alterações introduzidas na Lei 9394/1996 - LDBEN pela Lei 12.796/2013 que vem impactando as políticas, as ações e/ou as práticas educativas para a Educação Infantil brasileira, a saber: 1. Obrigatoriedade de matrícula a partir dos quatro anos: implicações para as crianças, para as políticas públicas e para as famílias; 2. O currículo da Educação Infantil; 3. Profissionais da Educação Infantil: salário, carreira e formação.

Movimentos sociais nacionais ${ }^{3}$, estaduais e regionais, compostos por diferentes instâncias, dentre elas as universidades, associações de pós-graduação e pesquisa, redes de proteção lutam pelos direitos das crianças e, fundamentalmente, pressionam para que as políticas públicas sejam construídas considerando não só a concepção de infância, a concepção de cuidar e educar, a formação de educadoras, como também explicitam reivindicações aos órgãos competentes tais como Ministério da Educação (MEC), União Nacional dos Dirigentes Municipais de Educação (UNDIME), Conselho Nacional de Secretários de Educação (CONSEd), União dos Conselhos Nacionais de Educação (UNCME), Fórum Nacional dos Conselhos Municipais de Educação

2 A origem do labirinto é o palácio cretense de Minos, onde estava encerrado o Minotauro e de onde Teseu só conseguiu sair com a ajuda do fio de Ariadne. Conservam-se, pois, em suma, a complicação de seu plano e a dificuldade de seu percurso (CHEVALIER e GHEERBRANT, 1998, p. 530).

3 MIEIB - Movimento Interfóruns de Educação Infantil do Brasil. 
(FNCME), Congresso Nacional, Ministério Público, Agência Nacional de Vigilância Sanitária (ANVISA), Instituto Nacional de Estudos e Pesquisas (INEP)4.

Essas reivindicações abordam uma diversidade de temas que perpassam os regimes de colaboração entre os governos federal, estaduais e municipais tanto em relação ao acesso das crianças, quanto ao Custo Aluno Qualidade inicial (CAQi), ao financiamento e distribuição de brinquedos, livros de literatura bem como abordam as políticas públicas de formação inicial e continuada de professoras e demais profissionais que atuam na Educação Infantil para mencionar apenas alguns.

Reitero então a pergunta: haverá o fio de Ariadne? Há muitas possibilidades para os tensionamentos! Para adentrar no labirinto que se constitui a Educação Infantil, multiplicidades de fios têm que ser puxados, pois há um entrecruzamento de caminhos "dos quais alguns não têm saída e constituem assim impasses; no meio deles é mister descobrir a rota que conduz ao centro dessa bizarra teia de aranha" (CHEVALIER; GHEERBRANT, 1998, p. 530). E essa multiplicidade não comporta dicotomias tais como centro/periferia, teoria/prática e sim movimentos criando espaços... tecidos... tecelagens... redes... rizomas (GALLO, 2003). Labirintos de labirintos...

Nesse emaranhado de fios uma pergunta faz-se necessária: o que já se produziu, oficialmente, que reafirma que as crianças têm direito a um processo diferente de feminilização e masculinização de seus corpos? Cito aqui dois documentos oficiais do MEC: o Referencial Curricular Nacional para a Educação Infantil (BRASIL, 1998) e Os Critérios para o Atendimento em Creches que respeitem os Direitos Fundamentais das Crianças (CAMPOS; ROSEMBERG, 1997). No primeiro documento há o reconhecimento da importância da sexualidade na vida das pessoas:

a sexualidade tem grande importância no desenvolvimento e na vida psíquica das pessoas, pois independentemente da potencialidade reprodutiva, relaciona-se com o prazer, necessidade fundamental dos seres humanos (...) seu desenvolvimento é fortemente marcado pela cultura e pela história (...) a marca da cultura faz-se presente desde cedo no desenvolvimento da sexualidade infantil, por exemplo, na maneira como os adultos reagem aos primeiros movimentos exploratórios que as crianças fazem em seu corpo" (BRASIL, 1998, p. 17).

Dessa forma o compromisso ético-político com a criança pequena na Educação Infantil consiste em assumir que a educação para a sexualidade faz parte da vida das crianças e acontece nas relações que se estabelece com elas, mediando as perguntas que fazem e as possibilidades da percepção do próprio corpo e do corpo de seus pares - meninos e meninas, na descoberta dos prazeres.

O segundo Documento Oficial citado convida a engalfinhar gênero e sexualidade no cotidiano da Educação Infantil. Cuidar e educar nestas temáticas não requer explicações, aulas sobre o assunto, mas requer a atenção para as marcas das submissões dos corpos, tanto de meninos quanto de meninas e o quanto educadores e educadoras compactuam ou não com isso! Ou... tentam fazer diferente e diferença. Esses critérios, inequivocamente, estão na ordem do acontecimento, no

4 Ver Carta de Salvador - BA elaborada no decorrer do XXVII Encontro Nacional do MIEIB e do II Encontro Estadual de Educação Infantil do FBEI com o tema Educação Infantil e Justiça Social: direito da criança e dever do Estado realizado no período de 15 a 18 de novembro de 2011 em Salvador - BA (www.mieib.org.br). 
campo da micropolítica que Gallo (2007)5, deslocando as concepções de Deleuze e Guattari para o campo da educação, diz ultrapassar os limites das leis, das políticas e das determinações legais e que acontecem - ou não - no cotidiano das instituições.

No emaranhado dessas veredas pelos caminhos da Educação Infantil transversalizando gênero e sexualidade emaranham-se, portanto, a educação maior "que traduz-se num esforço macropolítico de pensar, organizar, implementar e gerir os processos educacionais como um grande sistema, determinando suas regras, suas metas, suas ações" (...) e a educação menor que "traduz-se num esforço micropolítico de criação e de produção cotidiana, em que professores e estudantes realizam os atos educativos, mas também nas microrrelações estabelecidas na instituição escolar como um todo" (GALLO, 2007, p. 28).

Outras perguntas empurram-nos para adentrar cada vez mais no labirinto: as relações entre educação menor e educação maior são de oposição, de contrariedade ou de complementaridade? A educação menor pode ser capturada pela educação maior? Acontecem resistências, inesperados, inusitados? Mas que labirinto é esse? Como é constituído? As palavras de Corazza (2002) descrevem o indescritível:

Eles são construídos com repartimentos polimorfos, de disposição esteticamente enredada, tortuosa, intrincada, que nunca repetem sua própria forma, sendo que tais feitios são justamente aqueles que os tornam um lugar complicado e, muitas vezes, inextricável e admiravelmente emaranhado. Seus corredores estão dispostos em uma ordem tumultuosa, que depois de neles entrar é quase impossível encontrar a saída, mesmo que desejemos. O traçado de seu desenho é formado por linhas sinuosas e imprevisíveis, das quais, quando se está dentro, não se tem a mínima ideia de onde levarão, nem onde estão seus pontos de fuga, ou mesmo aqueles de aprisionamento. Lugar onde muitas vezes é preciso voltar sobre os próprios passos, para encontrar outras possibilidades de continuar em movimento; ou então gritar bem alto, para que o som da própria voz seja a única a fazer companhia, e não se morra de solidão (p. 107, 108).

Nesse inusitado labirinto que se constitui o cotidiano da Educação Infantil, com foco nas temáticas de gênero e sexualidade, que caminhos investigativos (COSTA, 2002) foram percorridos para problematizar as falas das educadoras que atuam diretamente nas instituições que convivem nos processos educativos com a criança pequena?

\section{"O que pode ser dito?" Quem está autorizado a dizer?"}

Estas são perguntas de Foucault quando apresenta o conceito de enunciado nos livros A arqueologia do saber e As palavras e as coisas:

Foucault define enunciadonãopormeio deseus elementos formais (gramaticais, lingüísticos ou proposicionais), mas por suas conexões com um domínio epistemológico mais amplo que permitem que certas coisas sejam ditas e outras não, que certos enunciados sejam possíveis e outros não (...) O importante

5 Em Mil Platôs, Deleuze e Guattari abordam o tema da produção do conhecimento em dois modelos: a produção de um conhecimento "oficial", regulado pelo Estado, e de um conhecimento "marginal", que escapa a esse jogo de regulações. Ao primeiro chamam de ciência régia (ou ciência maior); ao segundo, de ciência nômade (ou ciência menor). A ciência régia funciona de acordo com os mecanismos da máquina de Estado; já a ciência nômade opera como máquina de guerra, no registro dos povos nômades, que não possuem Estado (GALLO, 2007, p. 25). 
para Foucault é descrever as regras de formação ou as condições de possibilidade dos enunciados (SILVA, 2000, p. 50).

Este é um conceito fundamental para levar-me a olhar o corpus de análise de minha pesquisa como "um conjunto de textos associados a inúmeras práticas sociais, a analisá-los igualmente como práticas que são, como constituidores de sujeitos e corpos” (FISCHER, 2002, p. 43).

Qual corpus? Falas de educadoras que atuam na Educação Infantil, em uma rede municipal de educação de uma cidade de aproximadamente 160.000 habitantes em Minas Gerais e que participaram, no decorrer do segundo semestre de 2011, de um curso de formação continuada na temática de gênero e sexualidade na infância. Para efeito dessa pesquisa foram registrados pelas participantes e depois transcritos ${ }^{6}$, depoimentos individuais que apresentavam cenas do cotidiano da Educação Infantil na temática de gênero e sexualidade.

Esse material empírico foi analisado na tentativa de buscar, na transversalidade das falas das educadoras, as potencialidades do conceito de enunciado de Foucault (1988, p. 32) - que é "sempre um acontecimento, que nem a língua nem o sentido podem esgotar inteiramente". A leitura exaustiva do referido material empírico fez-me elencar alguns pontos: a) os corpos das crianças são descritos, nomeados, veiculados na linguagem através de signos, de dispositivos de controle, de convenções, de limites; b) A religião desempenha um papel primordial no governo da espontaneidade da sensualidade da criança; c) A pedagogização do sexo da criança, dispositivo específico de saber e poder, transformou a criança masturbadora em objeto privilegiado da mesma vontade de saber; d) a infância é definida pelo adulto que desconsidera as especificidades da criança, submetendo-a às suas necessidades; e) a psicologia, a biologia, a psicanálise e a pedagogia subsidiam as concepções de infância, buscando formular concepções e imagens que circularam e circulam nas sociedades. Entre as famílias que matriculam as crianças na Educação Infantil prevalece, na maioria das vezes, a visão da criança como inocente; f) A infância é uma categoria que existe no espaço social em que é estabelecida, negociada, desestabilizada e reconstruída no decorrer da história da humanidade e, o poder, sob várias formas, coagiu corpos e mentes infantis mediante um mecanismo próprio que é a disciplina. O poder disciplinar produziu corpos dóceis e eficientes mediante mecanismos que conformam o espírito: regularidade, autoridade, limite, penalidade, culpa e recompensa; g) gênero e sexualidade estão emaranhados; h) Educação Maior e Educação Menor estão engalfinhadas; i) as resistências também surgem no cotidiano.

Nesse labirinto de conceitos apresento alguns temas que emergiram na fala das cursistas ${ }^{7}$, como acontecimentos no cotidiano da Educação Infantil: educação para a sexualidade; conflitos; os genitais das crianças; erotização precoce, sexualidade aflorada; textos culturais tais como novelas, músicas; religião. E tantos outros temas que o limite para as páginas deste trabalho impedem de discutir: violências sexuais; autoerotismos; jogos sexuais; uso do banheiro; brincadeiras de menino e brincadeiras de menina; homossexualidade; nascimento de bebês.

6 Tenho em mãos 82 páginas transcritas.

7 Transcrição literal de suas falas que serão apresentadas em itálico. Preservarei o anonimato caracterizando cada depoimento com letras. 


\section{Educação para a sexualidade}

Abordar o tema sexualidade e gênero na Educação Infantil é um bicho de sete cabeças (porém, muito bom de conhecer...). Para tal é necessário que tenhamos um certo conhecimento sobre o assunto. Uma frieza (daquelas que gela até a coluna!). Já que não podemos demonstrar que estamos inseguras e contar com a participação da família que, na maioria das vezes, arrepia o cabelo e vem pra cima da gente como se tivéssemos incitando o sexo nas crianças. Normalmente, torcemos para que aquela perguntinha básica não venha durante as conversas na rodinha, mas mais dia menos dia, ela aparece e ai é um terror: ficamos vermelhas, engolimos em seco. Às vezes gaguejamos e num susto, desconversamos e partimos para o próximo coleguinha. Ufa! (...) todos se tocam e não há aquela intenção de "bulinar" (que termo mais retrógrado!) um ao outro (Cursista A).

Jimena Furlani (2005) afirma que a discussão da sexualidade na escola fascina muitos e apavora outros. Ela diz que o melhor seria dizer que ela fascina e apavora, ao mesmo tempo. Os incômodos podem ser mobilizadores para as mudanças. Novamente aciono o conceito de enunciado de Foucault que "se amplia para abranger elementos tais como tabelas, gráficos, árvores genealógicas, organogramas, relatórios contábeis, grades curriculares, equações etc" (SILVA, 2000, p. 50). O que não pode ser dito nos currículos da Educação Infantil, chamado aqui de "grade"? Por que não inserir, intencional e sistematicamente, os temas de sexualidade e gênero sendo que os mesmos apaixonam as crianças? Quem tenta dizer sente gelar a coluna! Fica vermelha e engole em seco. E esbarra na vigilância das famílias!

Articula-se aqui Educação Maior e Educação Menor. A professora diz ser um bicho de sete cabeças lidar com o tema, afirma que precisa “entender" que o tema relaciona-se ao desejo e ao prazer mas o cotidiano está repleto de interdições. Ao mesmo tempo, ela sabe que há uma política governamental federal que, através da SECADI - Secretaria de Educação Continuada, Alfabetização, Diversidade e Inclusão, estimula as universidades a produzirem conhecimento na temática de gênero e sexualidade e justamente o curso que ela participa é resultante da parceria SECADI, universidade e Secretaria Municipal de Educação. Essa parceria resultou inúmeros materiais para subsidiar a formação de educadores e educadoras.

O incômodo é proporcional ao desconhecimento do tema. O convite é para mobilizar a escola e incluir gênero e sexualidade nos currículos e, decisivamente, inventar formas diferentes de abordálos, pois as questões da sexualidade não podem ser relegadas ao espaço das respostas certas e erradas - especialmente na Educação Infantil. Condições de possibilidades de enunciar tanto das crianças quanto das professoras.

\section{Conflitos}

Os coleguinhas do F. (4 anos) estavam passando a mão no bumbum dele. Ele procurou a coordenadora do Colégio e relatou o fato para ela. A coordenadora foi até a sala de F. e disse para todas as crianças:

- "Vocês não podem passar a mão no bumbum do F. É feio! Caso vocês continuem vou fazer uma fila aqui na frente com todos que estão fazendo isso e vou pedir para ele passar a mão também". 
Nesse momento uma criança levantou e disse:

- “Eu não vou fazer isso, não é certo” (Cursista B).

Por que será que a mediação de conflitos não considera a perspectiva das crianças? Por que será que a coordenadora é que tem, de maneira autoritária, que resolver a situação? Como educar e em qual perspectiva? Uma criança que passa a mão no bumbum de outra está sinalizando algo. Que tipo de Educação para a sexualidade existe? É na inexistência que ela existe? A professora desaparece dessa cena do cotidiano. A criança aciona a coordenadora, pois ela se constitui na autoridade. A proposta de resolução do conflito vem, autoritariamente, sem discussão, isto é, sugere que as crianças façam o mesmo com o menino. Poderia haver, a partir desse fato do cotidiano, uma discussão em que as crianças pudessem se manifestar, como iniciou a criança que se levanta e diz que não vai passar a mão no bumbum do colega?

Nesse jogo de relações micropolíticas que "é a base de uma sociedade democrática de fato, em que se possa viver no dissenso, sem apelo a consensos fabricados autoritariamente", Gallo recomenda a leitura de Rancière que "nos faz pensar a democracia de uma outra maneira, tratando a democracia de uma outra maneira, tratando a política como a arte de organizar as partes, na qual sempre há um incontado; por isso, a democracia se faz no dissenso" (GALLO, 2007, p. 24).

Assim, essa aparentemente simples cena do cotidiano embaralha não só sexualidade como também as questões éticas: o menino que procura a coordenadora para resolver o problema; a invisibilidade da educadora; o uso do corpo do outro; a concepção de infância como aquela que não fala; a resistência do menino que rejeita passar a mão no bumbum do colega.

\section{Os genitais das crianças}

Durante uma atividade em sala de aula, quando estávamos trabalhando com a letra $P$, surgiu, na relação de palavras ditas pelas crianças, as palavras PIPI e PERERECA. Foi um grande reboliço. Um alvoroço só!

Um aluno disse para mim: - "Tia! Os meninos têm pipi. O pipi é de fazer xixi”.

Outro aluno também disse: "Os meninos têm pipi e as meninas têm perereca. O mesmo menino que afirmou que os meninos têm pipi disse assim: minha mãe falou que minha avó tem perereca. Uma terceira aluna também disse: perereca é a mulher do sapo. É um bichinho. E começou a discussão sobre o assunto. (Cursista C).

No decorrer da aula, uma aluna (4 anos) chega até a mim e diz: "tia, a minha pichoca (nem sei se é assim que escreve) está ardendo". Eu então, surpresa com aquela palavra desconhecida, perguntei:

-A sua o quê?

“Pichoca tia, está ardendo”. Respondeu a menina apontando para a vagina.

Só aí compreeendi e aprendi o que era pichoca. 
Perguntei a ela o motivo da ardência e ela me respondeu que estava assada.(...)

Quando estávamos no banheiro, observei que realmente a menina estava com a vagina bastante assada. Expliquei a ela que teríamos que chamar a mãe para que ela tomasse as devidas providencias, tendo em vista que não tínhamos nenhum medicamento na escola. Enquanto aguardávamos a chegada da mãe, a menina que me ouviu dizer para sua mãe ao telefone que estava com a vagina assada, me fez a seguinte pergunta:

- "Tia, a sua mãe deixa vocêfalar palavrão?"

-(Hum!!) Não entendi.

- "É, eu ouvi vocêfalar um palavrão para minha mãe no telefone”.

Percebi que a menina se referiu à palavra vagina. Respondi a ela que vagina não era palavrão, que era o verdadeiro nome dessa parte do corpo das mulheres. E que pichoca era um apelido. (Cursista $\mathrm{D})$.

Este é um depoimento longo e optei por relatar o seu desenrolar. A mãe recebeu o telefonema da professora, compareceu à escola para buscar a filha e levá-la ao médico. No dia seguinte, quando a professora chegou ao Centro de Educação Infantil, informa em seu relato: "havia uma comissão para me receber; lá estava a mãe da garota "assada”, a avó e a coordenadora pedagógica”. A reunião aconteceu a portas fechadas e a mãe inicia a "queixa" contra a professora: houve uma conduta inadequada: "ontem levei minha filha ao médico e quando ele foi examiná-la ele disse à ela que precisaria olhar a pichoca dela. No mesmo instante a criança respondeu: não é pichoca, é vagina, o nome dela é vagina; pichoca é apelido". E o médico perguntou quem disse isso e a menina respondeu que foi "a tia da escola". A mãe revelou o quanto ficou envergonhada, o médico constrangido e ficou abismado de uma professora ensinar isso para uma criança de 4 anos. A professora conta em detalhes os seus argumentos. Segundo ela a mãe ficou sem resposta; levantouse e foi embora mas antes "passou na sala de aula, pegou a filha e nunca mais voltou à escola".

Quanta contradição quando a sexualidade de crianças pequenas está em pauta. O nome dos genitais na atividade desencadeada pela professora $\mathrm{C}$ foi fonte de risos, brincadeiras, aprendizados, diferenças entre o animal perereca e o apelido da vagina. Nessa dinâmica da interlocução uma criança disse que "mulher tem que gostar de homem”. Muitas possibilidades para problematizações. Perguntas que podem ser geradoras de outras perguntas e as respostas não são consensuais, pois sexualidade e gênero imbricam-se com as diferenças: de valores, de religião, de crenças, de costumes, de concepções, de significações, que também se entrelaçam com o dito e o não dito, o pode e o não pode, prazeres e desprazeres, alegrias e tristezas, vergonhas, culpas, insinuações, segundas intenções. Havia condições de possibilidades para o desenrolar de processos de letramento ${ }^{8}$ Já no segundo relato a professora esbarrou em adultos que desconhecem que as crianças são seres sexuados e que poderiam expressar natural e espontaneamente sua sexualidade e também suas ideias sobre a temática. Quanta confusão na construção desse conhecimento pela criança: primeiro pensa que a professora está falando palavrão; o médico fica chocado e manifestou isso durante a

8 Cf. KLEIMAN, Ângela B. (org) Os significados do letramento: uma nova perspectiva sobre a prática social da escrita. Campinas: Mercado de Letras. 1995. 
consulta. A criança lê a linguagem corporal do adulto. A mãe vai até a escola junto com a avó e depois da reunião retira a filha da escola.

O que foi dito nesses dois depoimentos, o que não foi dito; o que a professora não disse em relação ao fato de que mulher tem que gostar de homem? Por que a professora é chamada de "tia"? Quando Foucault diz que a crítica se apoia no acontecimento, afirmo com ele que nesses depoimentos/ acontecimentos não pretendo assumir um discurso salvacionista e messiânico:

A crítica implica uma analítica que não acusa nem lastima, uma vez que isso significaria pressupor, de antemão, uma verdade, um mundo melhor, em relação à qual ou ao qual a análise se daria. Se quisermos um mundo melhor, teremos de inventá-lo, já sabendo que conforme vamos nos deslocando para ele, ele vai mudando de lugar (FOUCAULT apud VEIGA-NETO, 2005, p. 30-31).

Essa crítica implica em inserir intencional e sistematicamente a educação para a sexualidade nos currículos da Educação Infantil contemplando a formação de educadoras e o compromisso coletivo da instituição.

\section{Erotização precoce; sexualidade aflorada}

É muito claro o desenvolvimento da sexualidade na criança e com isso presenciamos alguns fatos em sala de aula. Onde trabalho, com a faixa etária de 3 anos, tem duas crianças que formaram uma parceria desde o primeiro dia que se conheceram. É como um casal e para eles foi como amor à primeira vista. A amizade foi crescendo e eles começaram a fazer tudo juntos. O menino quer muitas vezes até levar a menina ao banheiro; é preciso ficar mediando situações entre eles constantemente para evitar brigas com as outras crianças. Os dois interagem normalmente com as outras crianças, porém não permitem o toque fisico dos outros em nenhum dos dois. Quando acontece algum conflito que envolve um deles, o outro está sempre pronto para defender. Eles fazem tudo juntos; sentam no refeitório, na mesa para fazer atividades; só brincam quando os dois podem brincar juntos. Se por algum motivo uma das crianças disser que um dos dois não pode brincar, o outro também sai da brincadeira. Andam sempre de mãos dadas e quando dá se abraçam.

A mãe da menina pediu a minha ajuda para separá-los, pois por motivos pessoais, ela não queria essa proximidade dos dois e também porque em casa a menina só fala do companheiro (...) e agora está dizendo que quer ir para a escolinha periodo integral (pois o horário dela é apenas meio período) para poder dormir no colchão junto com seu amigo.

\section{(...)}

Essa é uma situação que vivencio em minha sala de trabalho que demonstra, de forma clara, que a criança, desde pequena, faz suas escolhas afetivas e revelam que sua sexualidade está aflorada (...) (Cursista E).

Porém, muitas atitudes do R. demonstram uma erotização fora do normal, como se tivesse visto cenas (Cursista F).

Trabalhando com jardim II, no periodo da manhã com crianças de 5 anos, tenho um aluno que é muito aflorado para a sexualidade (Cursista G).

As crianças convivem cotidianamente com cenas de sexo, seja em casa, seja na rua. Elas são motivadas a erotização precoce, através da imitação de comportamentos sugeridos por músicas e coreografias, que estimulam a sexualidade e a sensualidade (Cursista $\mathrm{H}$ ). 
Essas palavras: erotização precoce e sexualidade aflorada rotulam muitas vezes as sexualidades das crianças. Por que será que o adulto, muitas vezes, incomoda-se tanto quando as crianças brincam com seus corpos, experimentam prazeres, descobrem-se meninos e meninas na interação? Por que será que a auto exploração e a exploração do corpo de outra criança, que auxilia na compreensão do próprio corpo e do prazer são, muitas vezes, impedidos? Nesses três depoimentos o governo exercido por múltiplas forças constituem autoridades que se consideram capazes de vigiar, julgar, marcar a sexualidade das crianças; de proclamarem verdades sobre elas: o que é certo/errado? O que é normal? Que discursos educacionais, científicos, médicos, jurídicos, morais, religiosos perpassam as sexualidades das crianças produzidas culturalmente?

As crianças sentem prazer, em todas as idades, em manipular genitais, afagar, beijar, tocar um ao outro; são gestos comuns entremeados de muito riso e cócegas, com o mesmo ou outro sexo. O que as crianças veem na TV, nas praças públicas, nas relações entre jovens, adultos constitui-se num rico material para a elaboração tanto de suas concepções de sexualidade e gênero quanto das expressões de sua sexualidade. Os adultos - familiares, professores e professoras têm expectativas diferentes quanto a padrões de comportamento apropriados para meninos e meninas.

Larossa (1999) fala da "medida da nossa responsabilidade" frente a esse enigma que é a criança. Do desafio que é concebê-la em sua heterogeneidade em relação ao adulto. E acrescento, o desafio que é favorecer a expressão de sentimentos, desejos, prazeres, hipóteses e descobertas, sem tabus e preconceitos.

\section{Textos culturais: novelas, músicas}

É comum no dia a dia da escola ouvirmos relatos das crianças contando com detalhes cenas das novelas que assistiram com a família.

(...) As músicas que ouvem são apelos à violência, a banalização do sexo e a desvalorização da mulher.

(...) Há um garoto em nossa unidade que enquanto faz as suas atividades, brinca no recreio ou no parquinho, cantarola o tempo todo:

Toma negona, toma chupeta

Toma negona, na boca e na bochecha

Gugu dada, gugu dada

Se você pedir painho vai te dar

Cada depoimento apresentado incita-nos a pensar nesse processo educativo na primeira etapa da Educação Básica, em suas múltiplas inter-relações pedagógicas, histórias, sociais, econômicas, políticas e culturais. Assim sendo, as relações de gênero e a sexualidade embora não inseridas intencionalmente nos Projetos Político Pedagógicos das Instituições de Educação Infantil emergem com uma força grande na fala das profissionais a partir das resistências das crianças: "e tudo é proibido. Então falamos!" brilhantemente poetizado por Carlos Drummond de Andrade (1997). 
Nesse movimento proposto neste texto que é penetrar no labirinto da Educação Infantil, esse fio puxado chega novamente até a Estrutura Curricular para a criança pequena: constitui-se em um empreendimento ético e político que, constantemente esbarra nos efeitos de verdade inerentes às práticas discursivas. A cultura é campo de luta em torno da construção e da imposição de significados sobre o mundo social (SILVA, 1999a).

Nesse campo de luta, as relações de gênero e a sexualidade, se inseridas no currículo que é texto, discurso, matéria significante, ato político, não pode ser separado das relações de poder que navegam pela disseminação de sentido, pela polissemia, pela produção de identidades voltadas para o questionamento e para a crítica. Também da criança pequena (SILVA, 1999b).

Assim, novas práticas podem ser redefinidas, questionadas, disputadas, contestadas, tanto na análise dos artefatos culturais que já fazem parte do cotidiano das crianças quanto no acesso da criança a outros textos culturais com vistas a ampliar seus campos de significação.

\section{Religião}

Observei que S. (4 anos) coçou muito os genitais. Ele não me deixou olhar. Por favor (dirigindo-me à mãe) observe, pode ser alguma alergia.

Então a mãe disse:

- "Não acredito meu Deus! Ele está fazendo isso de novo!"

E foi embora arrasada não dizendo absolutamente mais nada. Passados 5 dias ela voltou à escola e disse:

- "Olha, eu sei que meu filho estava fazendo aquilo que eu nem tenho coragem de falar. Mas ele não vai fazer isso mais. Eu e meu marido compramos uma pomadinha e o levamos para conversar com o pastor e deu tudo certo!" (Cursista I).

Tenho uma aluna que venho observando o comportamento dela e por motivos de religião e pela educação que a mãe lhe dá, apresenta atitudes bem diferentes em relação à turma de maternal II (3-4 anos). Passar esmalte colorido, brincos ou certos tipos de música ela fala que não é de Deus. (Cursista J).

O discurso religioso é poderoso no controle da sexualidade. Foucault, citado por Veiga-Neto (2005, p. 17), foi aquele que "melhor nos mostrou como as práticas e os saberes vêm funcionando, nos últimos quatro séculos, para fabricar a modernidade e o assim chamado sujeito moderno". Para fabricar o controle dos corpos das crianças, o referido discurso religioso repete incessantemente que não existe intimidade suscetível de escapar ao olhar de Deus. Os depoimentos acima informam que o controle continua e a família leva a criança para conversar com o pastor. Em meio a todas essas contradições a infância se torna a idade fundadora da vida e a criança transforma-se em pessoa, alvo de métodos intervencionistas e normatizadores também da medicina que não se limitou à família, mas alastrou-se pelas instituições educacionais e correcionais, com o discurso da infância em perigo e da infância perigosa. As crianças, então, passaram a ocupar espaços de maior vigilância: a casa ou a escola, sob a medicalização da sexualidade. 
O século XIX deu à sexualidade o estatuto de ciência. A tolerância sexual acontecia em consonância com o meio, a idade, os atos e o gênero: a diferença e desigualdade entre homens e mulheres era enorme. No entanto, já a partir do século XVIII, quatro grandes conjuntos estratégicos desenvolveram dispositivos específicos de saber e poder a respeito do sexo: histerização do corpo da mulher, pedagogização do sexo da criança, socialização das condutas de procriação e psiquiatrização do prazer perverso. Dessa forma tornaram-se objetos privilegiados de saber: a mulher histérica, a criança masturbadora, o casal malthusiano e o adulto perverso (FOUCAULT, 1988).

Essa cientifização do sexo retomou os métodos do cristianismo. Em relação à sexualidade das crianças, esta já era tema da pedagogia espiritual do cristianismo. A infância passou a ser objeto de intervenção higiênica e disciplinar. O poder do pai foi questionado e a importância da mulher/mãe na proteção à criança foi exaltada criando-se uma nova organização doméstica em que o pai dava a proteção material e a mãe a iniciação na educação.

Em nome da proteção à infância, concebendo a criança como entidade físico-moral amorfa, com o trunfo da mortalidade infantil nas mãos e da nocividade familiar, os médicos esboçaram trabalhos sobre amamentação, regras de conservação da saúde e desenvolvimento das forças físicas e intelectuais. A técnica de uma educação higiênica era a da criação de hábitos para prevenir as "más inclinações" (COSTA, 1989).

Também, com a mesma ideia de sanar a inconsequência das famílias, a organização do dispositivo antimasturbação nos colégios foi amplamente utilizada para educar as crianças com o objetivo social. A preocupação com a sexualidade infantil e o perigo que representava para a saúde física, moral e intelectual dos jovens fez com que os médicos exercessem o seu controle especialmente em relação à masturbação.

Nas últimas décadas do século XIX o ambiente familiar recuperou a educação dos filhos, inclusive a educação sexual que passava pelo não-dito, pelo falar o mínimo possível. A mulher estava pronta para desempenhar a tarefa da mãe higiênica, papel outrora desenvolvido pelos professores medicalizados.

Século XXI e os depoimentos/acontecimentos trazem cenas do cotidiano das instituições de Educação Infantil em que a professora é a "tia", a expressão da sexualidade das crianças é "vigiada e punida"... A criança é levada ao pastor porque toca seus genitais.

\section{Considerações finais}

Termino o que não tem fim, pois conforme anunciado no decorrer deste trabalho, quantos enunciados há ainda para problematizar referentes a pesquisa com as educadoras que atuam na Educação Infantil, agrupados sob diversos temas, a saber: violências sexuais; autoerotismo; jogos sexuais; uso do banheiro; brincadeiras de menino e brincadeiras de menina; homossexualidade; nascimento de bebês. 
Entrei no labirinto que se constitui a Educação Infantil emaranhando as macropolíticas e as micropolíticas, a legislação já conquistada e o que ainda há para conquistar, puxando também os fios de gênero e sexualidade. Pergunto com Corazza (2002): “onde estão os pontos de fuga, ou mesmo de aprisionamento"? Quais os gritos ainda têm que ser fortemente emitidos pelos movimentos sociais, universidades, ongs, dentre outros, para que se efetivem as políticas públicas imbricando tudo isso com as relações de gênero e as expressões da sexualidade da criança pequena nas instituições de Educação Infantil?

Como produzir uma nova forma de ser em grupo que se dá nas atividades desenvolvidas com as crianças, que se dá no local de trabalho, que se dá na relação com o sindicato, produzindo cultura, produzindo política, produzindo educação, já que essa é a nossa ferramenta? Em outros termos, a questão é: como pensar e produzir, nesse início de século XXI, uma educação revolucionária? (GALLO, 2003).

Tudo isso requer agitar os conceitos de infâncias, de políticas, de gêneros, de sexualidades, de currículos, de Educação Infantil. Isso requer também outro referencial teórico. As concepções tradicionais são perturbadas pelas ideias de Michel Foucault que, dentre tantas ferramentas teóricas, instiga a perceber o poder não apenas como coercitivo e negativo, mas como produtivo e positivo. Isso requer "manobras", "técnicas”, "disposições”, as quais são, por sua vez, resistidas e contestadas, respondidas, absorvidas, aceitas ou transformadas (FOUCAULT, 1988).

Resistir, portanto, é criar! É acionar quantas “Ariadnes” forem possíveis para-com multiplicidades de fios - adentrar nesse labirinto que é a Educação Infantil.

\section{Referências}

ANDRADE, C. D. A senha do mundo. Rio de Janeiro: Record, 1997.

BRASIL. Referencial Curricular Nacional para a Educação Infantil. Ministério da Educação e do Desporto, Secretaria de Educação Fundamental. Brasília: MEC/SEF, 1998.

CAMPOS, M. M.; ROSEMBERG, F.; FERREIRA, I. M. Creches e pré-escolas no Brasil. 2. ed. São Paulo: Cortez, 1995.

CAMPOS, M. M.; ROSEMBERG, F. Critérios para um atendimento em creches que respeitem os direitos fundamentais das crianças. Brasília: MEC/SEB, 1997.

CHEVALIER, J.; GHEERBRANT, A. Dicionário de símbolos. Mitos, sonhos, costumes, gestos, formas, figuras, cores, números. Rio de Janeiro: José Olympio, 1998.

CORAZZA, S. M. Labirintos da pesquisa, diante dos ferrolhos. In: COSTA, M. V. (Org.)

Caminhos investigativos. Novos olhares na pesquisa em educação. 2. ed. Rio de Janeiro: DP\&A, 2002.

COSTA, J. F. Ordem médica e norma familiar. Rio de Janeiro: Edições Graal Ltda, 1989.

COSTA, M. V. (Org.) Caminhos investigativos. Novos olhares na pesquisa em educação. 2. ed.

Rio de Janeiro: DP\&A, 2002.

FISHER, R.M.B. A paixão de trabalhar com Foucault. In: COSTA, M. V. (Org.) Caminhos 
investigativos. Novos olhares na pesquisa em educação. 2. ed. Rio de Janeiro: DP\&A, 2002. FOUCAULT, M. História da Sexualidade I: a vontade de saber. Tradução de Maria Thereza da Costa Albuquerque e J. A. Guilhon Albuquerque. Rio de Janeiro: Edições Graal, 1988.

FURLANI, J. Sexos, sexualidades e gêneros - monstruosidades no Currículo da Educação Sexual. Texto apresentado na $28^{a}$. Reunião Anual da ANPEd - Associação Nacional de Pósgraduação e Pesquisa em Educação no GT 23 - Gênero, sexualidade e educação, 2005. Disponível em <www.ded.ufla.br-gt23>. Acesso em: 05 mar. 2012.

LAROSSA, J. O enigma da infância. In. LARROSA, J. Pedagogia profana: danças, piruetas e mascaradas. Tradução de Antônio Veiga-Neto. Belo Horizonte: Autêntica, 1999.

GALLO, S. Deleuze \& a Educação. Belo Horizonte: Editora Autêntica, 2003.

GALLO, S. Acontecimento e resistência: Educação menor no cotidiano da Escola. In:

CAMARGO, A. M. F.; MARIGUELA, M. (Org.) Cotidiano escolar: emergência e invenção. Piracicaba: Jacintha, 2007.

SILVA, T. T. da. Teoria cultural e educação. Um vocabulário crítico. Belo Horizonte: Autêntica, 2000. . O currículo como fetiche. Belo Horizonte: Autêntica,1999a.

. Documentos de identidade. Uma introdução às teorias do currículo. Belo Horizonte: Autêntica, 1999b.

VEIGA-NETO, A. Foucault e a educação. 2. ed. Belo Horizonte: Autêntica, 2005. 